\title{
RESPON DARI PENDUDUK LOKAL DAN WISATAWAN MANCANEGARA YANG MENGENDARAI KENDARAAN BERMOTOR DI BALI TERHADAP BATAS KECEPATAN PADA RUAS JALAN NASIONAL
}

\section{The Response of Drivers and Riders of Local Resident and International Tourist to Speed Limitation on The National Road in Bali}

\author{
Dewa Made Priyantha Wedagama \\ Program Studi Teknik Sipil \\ Fakultas Teknik \\ Universitas Udayana \\ Kampus Bukit Jimbaran, Bali \\ priyantha@civil.unud.ac.id
}

\author{
I Made Kariyana \\ Program Studi Teknik Sipil \\ Fakultas Teknik \\ Universitas Ngurah Rai \\ Penatih, Denpasar, Bali \\ made.kariyana@unr.ac.id
}

\author{
Andyka Kusuma \\ Departemen Teknik Sipil \\ Fakultas Teknik \\ Universitas Indonesia \\ Kampus Baru UI \\ Depok, Jawa Barat \\ andyka.k@eng.ui.ac.id
}

\begin{abstract}
This study analyses the responses of local residents and international tourist drivers and riders to speed limits on the national road in Bali. A self-reported questionnaire survey was distributed among representative samples of local residents and international tourists in Bali. The questionnaire consisted of variables of demographic factors, riding history, driving/riding experiences on the national road, perceptions on speed sign, involvement in traffic accidents and offenses, attitude, intention, and behavior toward speeding. The results show that demographic factors, involvement in traffic accidents and offenses, experience in driving/riding on national roads, and riding history negatively and significantly influenced perceptions on speed signs for local drivers/riders and on attitudes towards speeding for international tourist driver/riders. Also, attitudes towards speeding have significant and positive influences on intention towards speeding for local drivers/riders. Local residents and international tourists have their own factors that significantly influenced their perceptions of speed limitation on national roads in Bali.
\end{abstract}

Keywords: international tourists, local residents, national road, speed limit

\begin{abstract}
Abstrak
Studi ini menganalisis respon pengendara kendaraan bermotor dari penduduk lokal dan wisatawan mancanegara terhadap batas kecepatan di jalan nasional di Bali. Pengumpulan data dilakukan dengan kuisioner yang didistribusikan kepada sampel yang representatif dari penduduk lokal dan wisatawan mancanegara di Bali. Kuisioner berisi pertanyaan terkait faktor demografis, pengalaman berkendara di jalan nasional, persepsi rambu kecepatan, keterlibatan dalam kecelakaan dan pelanggaran lalu lintas, sikap, prilaku dan niat untuk ngebut. Hasil studi menunjukkan bahwa faktor demografis, keterlibatan dalam kecelakaan dan pelanggaran lalu lintas, pengalaman berkendara di jalan nasional secara signifikan dan negatif berpengaruh terhadap persepsi terhadap rambu kecepatan bagi penduduk lokal dan terhadap sikap terkait ngebut bagi wisatawan international. Sikap terkait ngebut berdampak positif dan signifikan terhadap tujuan ngebut bagi pengendara penduduk lokal. Studi ini menunjukkan bahwa penduduk lokal dan wisatawan mancanegara dipengaruhi oleh faktor yang berbeda terkait persepsi tentang batas kecepatan pada jalan nasional di Bali.
\end{abstract}

Kata kunci: wisatawan mancanegara, penduduk lokal, jalan nasional, batas kecepatan 


\section{PENDAHULUAN}

Pulau Bali merupakan salah satu tujuan wisata favorit di Indonesia dimana sepeda motor merupakan moda transportasi yang paling banyak digunakan untuk melakukan perjalanan di pulau ini. Data menunjukkan bahwa moda transportasi di Bali lebih dari $80 \%$ adalah sepeda motor (Badan Pusat Statistik Provinsi Bali, 2018). Wisatawan mancanegara lebih banyak menyewa mobil dengan atau tanpa sopir atau sepeda motor daripada menggunakan angkutan umum karena kurangnya kuantitas dan kualitas layanan angkutan umum di Bali. Selain itu, peraturan dan regulasi lalu lintas seringkali tidak dipatuhi oleh pengendara kendaraan bermotor di jalan raya di Bali (Wedagama, 2017). Sebagi contoh, sepeda motor seringkali mendahului kendaraan lain dari sisi kiri atau masuk ke dalam pusaran arus lalu lintas tanpa melihat ke kanan atau kiri dan berharap pengendara lain dalam arus utama lalu lintas mengalah.

Beberapa studi yang sudah dilakukan di Indonesia telah meneliti tentang berbagai faktor psikologi dan psikososial yang mempengaruhi prilaku pengendara sepeda motor penduduk lokal terkait tujuan, agresi, sensasi dan sikap terhadap ngebut (Joewono et.al., 2015; Susilo et.al., 2015). Sementara itu, wisatawan mancanegara yang mengendarai sepeda motor dan keselamatan lalu lintasnya bersifat sangat kompleks. Hal ini karena banyak wisatawan mancanegara masih awam terkait resiko yang akan mereka hadapi saat berkendara dan ngebut di jalan raya dengan situasi lalu lintas campuran yang tidak biasa bagi mereka. Wisatawan saat memilih moda transportasinya cepat atau lambat akan menyadari perihal keselamatan dirinya saat berkendara di jalan raya (Nutsugbodo et.al, 2018). Resiko ngebut yang dihadapi penduduk lokal dan wisatawan asing merupakan bidang kajian dari peneliti keselamatan lalu lintas karena adanya kemungkinan mereka terlibat dalam suatu kecelakaan lalu lintas.

Studi-studi sebelumnya menyimpulkan bahwa investigasi dan analisis pengaruh dari berbagai persepsi pengendara kendaraan bermotor sangat penting di dalam perencanaan dan penyusunan respon yang konstruktif untuk perbaikan keselamatan lalu lintas (Duong and Parker, 2018; Kaplan et.al, 2018). Walaupun sepeda motor merupakan moda transportasi yang favorit di Bali dan banyak terlibat dalam kecelakaan lalu lintas, penelitian keselamatan lalu lintas sangat diperlukan melalui pengujian berbagai macam faktor-faktor psikososial yang berpengaruh terhadap prilaku ngebut. Penelitian ini juga sangat penting untuk perbaikan dan strategi keselamatan lalu lintas masa mendatang khususnya di Bali.

Tujuan dari penelitian ini adalah untuk investigasi, penyusunan model dan analisis persepsi pengendara kendaraan bermotor terhadap batas kecepatan pada ruas jalan nasional di Bali. Studi ini ada pada cakupan keselamatan lalu lintas dengan sampel penduduk lokal dan wisatawan asing di Bali. Penelitian ini meliputi karakteristik sosio demografis pengendara kendaraan bermotor seperti jenis kelamin, umur, tingkat pendidikan, kepemilikan surat ijin mengemudi, eksposur yaitu jarak perjalanan yang sudah pernah ditempuh dan keterlibatan dalam kecelakaan minor dan sebagai korbannya dalam perioda 3 tahun terakhir. Selain itu, penduduk lokal dan wisatawan mancanegara dapat menggunakan hasil studi ini untuk memperbaiki pola berkendaranya saat di jalan raya.

Penelitian ini diharapkan menjembatani pemahaman permasalahan keselamatan lalu lintas dari sudut pandang penduduk lokal dan wisatawan mancanegara terhadap batas kecepatan khususnya pada ruas jalan nasional. Selain itu, penelitian ini juga dapat menyediakan data penting terkait komponen-komponen yang berpengaruh terhadap prilaku beresiko dari 
pengendara kendaraan bermotor penduduk lokal dan wisatawan mancanegara khususnya ngebut. Hasil studi ini memberikan informasi di dalam menyusun sasaran/target khusus dan kampanye keselamatan lalu lintas. Kampanye penurunan kecepatan, implementasi dan penegakan hukum dianggap sangat penting untuk tujuan menurunkan korban meninggal dunia dan luka-luka berat.

\section{METODE PENELITIAN}

Penelitian ini merupakan suatu studi cross sectional yang menggunakan kuisioner swalapor atau self-reported questionnaire (Ulleberg and Rundmo, 2003) yang diperuntukkan bagi penduduk lokal dan wisatawan mancangera yang mengendarai kendaraan bermotor di Bali. Kuisioner ini disusun mengacu kepada Teori Prilaku yang Terencana atau Theory of Planned Behaviour (TPB) yang mengaitkan antara norma yang diyakini seseorang dan prilakunya (Ajzen, 1991) seperti diperlihatkan pada Gambar 1.

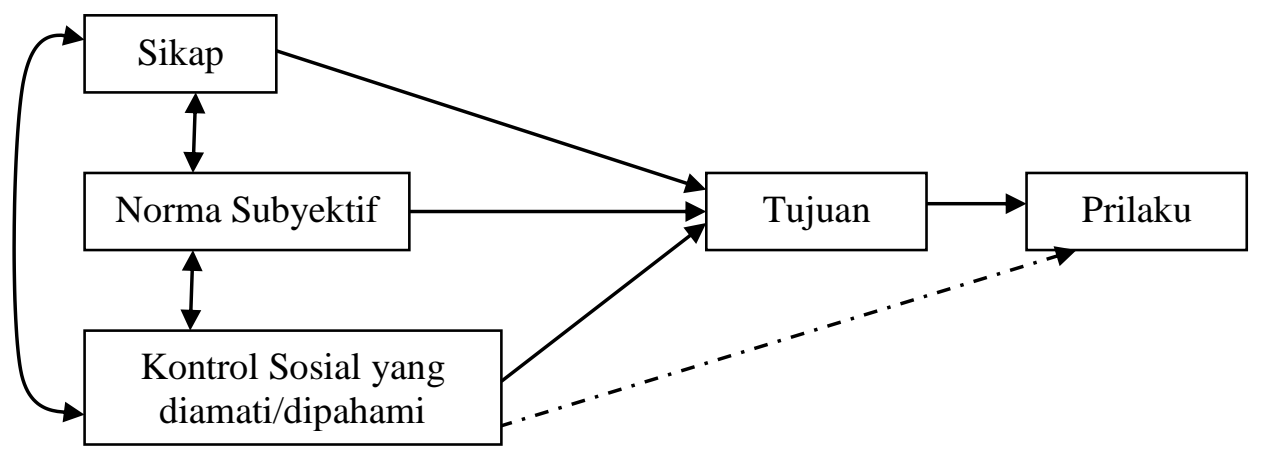

Gambar 1. Theory of planned behaviour (Ajzen, 1991)

Kuisioner swalapor (the self-reported questionnaires) didistribusikan secara acak kepada masing-masing 300 orang penduduk lokal dan wisatawan mancanegara yang mengendarai kendaraan bermotor di Bali. Metode Analisis Komponen Utama atau Principal Component Analysis/PCA dan Model Persamaan Struktural atau Structural Equation Model /SEM) digunakan untuk analisis data, menyusun model statistik dan menginterpretasi hasil model (Hair, et.al., 2010; Hooper, et.al, 2008; Lai, 2011).

Tabel 1. Item-item pada kuesioner

\begin{tabular}{|c|c|c|}
\hline No. & Items & Factor \\
\hline DF1. & Umur & \multirow{3}{*}{ Faktor Demografi } \\
\hline DF2. & Jenis kelamin & \\
\hline DF3. & Tingkat pendidikan & \\
\hline RH1. & Kepemilikan Surat Ijin Mengemudi (SIM) & \multirow{4}{*}{ Catatan Berkendara } \\
\hline RH2. & Tipe kendaraan yang paling sering dikendarai & \\
\hline RH3. & Pengalaman berkendara kendaraan bermotor & \\
\hline RH4. & Lama mengendarai sepeda motor dalam sehari & \\
\hline NR1. & Frekuensi berkendara pada jalan nasional & \multirow{2}{*}{ Berkendara di Jalan Nasional } \\
\hline NR2. & Waktu berkendara pada ruas jalan nasional & \\
\hline
\end{tabular}




\begin{tabular}{cll}
\hline No. & \multicolumn{1}{c}{ Items } & \multicolumn{1}{c}{ Factor } \\
\hline SS1. & Menjaga batas kecepatan dengan rambu kecepatan & \\
SS2. & Rambu kecepatan untuk cek kecepatan & \\
SS3. & Rambu kecepatan untuk keselamatan lalu lintas & Persepsi terhadap Rambu Kecepatan \\
SS4. & Rambu kecepatan untuk pengurangan waktu tempuh & \\
SS5. & Manfaat dan tujuan rambu kecepatan & \\
SS6. & Batas atas dan bawah kecepatan pada jalan nasional & \\
\hline AO1. & Terlibat kecelakaan lalu lintas 12 bulan terakhir & Keterlibatan dalam Kecelakaan dan \\
AO2. & Terlibat pelanggaran lalu lintas 12 bulan terakhir & Pelanggaran Lalu Lintas \\
\hline AS22a-22k & Sikap terkait ngebut & Sikap, Tujuan dan Prilaku Ngebut \\
IS23a-23k & Tujuan ngebut & \\
BS24a-24g & Prilaku ngebut & \\
\hline
\end{tabular}

Kuisioner terdiri dari enam (6) item yang memuat total 49 pertanyaan seperti diperlihatkan pada Tabel 1. Metode swalapor digunakan pada penelitian ini karena metode ini dapat memberikan berbagai macam pertanyaan terkait sikap responden yang dapat dicatat secara baik (Rhodes and Pivik, 2011). Metode ini mengikuti studi sebelumnya dari Ulleberg and Rundmo (2003) yang menyimpulkan bahwa metode swalapor prilaku berkendara memperlihatkan pola prilaku yang stabil dan memprediksi indikator yang konsisten bagi prilaku berkendara. Data yang dikumpulkan dari responden termasuk faktor demografi (DF1-DF3), catatan selama mengendarai sepeda motor/catatan berkendara (RH1-RH4), pengalaman berkendara pada ruas jalan nasional (NR1-NR2), persepsi terhadap rambu kecepatan (SS1-SS6), keterlibatan dalam kecelakaan dan pelanggaran lalu lintas (AO1AO2) dan sikap, tujuan dan prilaku ngebut (AS22a-AS22k; IS22a-IS22k; 1 = sangat tidak setuju sampai 5 = sangat setuju; BS22a-BS22g; 1 = sangat tidak mungkin sampai $5=$ sangat mungkin). Tabel 1 memperlihatkan semua item pada kuisioner dan jumlah pertanyaan pada setiap item.

Rata-rata umur sampel penduduk lokal adalah 33.4 tahun (jangkauan dari umur 18 sampai 62 tahun) terdiri dari 89 pria dan 62 wanita. Sementara itu, rata-rata umur sampel wisatawan mancanegara adalah 30 tahun (jangkauan dari umur 18 sampai 68 tahun) terdiri dari 58 pria dan 43 wanita. Proporsi pengendara pria dan wanita untuk penduduk lokal berturut-turut adalah $58.94 \%$ dan $41.06 \%$, sementara untuk wisatawan mancanegara adalah berturut-turut $56.31 \%$ dan $41.75 \%$.

Berdasarkan data yang dikumpulkan, persentase pengendara kendaraan bermotor usia muda (dari usia 18 sampai 25 tahun) dari penduduk lokal dan wisatawan mancanegara adalah berturut-turut $46.36 \%$ dan $38.83 \%$. Sementara itu, persentase usia antara 26 dan 60 tahun dari penduduk lokal dan wisatawan mancanegara adalah berturut-turut $51.66 \%$ dan $57.28 \%$. Persentase pengendara kendaraan bermotor berusia diatas 60 dari penduduk lokal dan wisatawan mancanegara adalah berturut-turut $1.32 \%$ dan $2.91 \%$. Tingkat pendidikan responden lebih dari 50\% merupakan lulusan sekolah menengah atas bagi penduduk lokal dan lulusan akademi atau universitas bagi wisatawan mancanegara.

Persentase penduduk lokal yang tidak terlibat dalam kecelakaan dan pelanggaran lalu lintas selama 12 bulan teakhir adalah berturut-turut sebanyak $70.87 \%$ dan $72.82 \%$. Pada saat 
yang bersamaan, wisatawan mancanegara yang tidak terlibat dalam kecelakaan dan pelanggaran lalu lintas selama 12 bulan terakhir berturut-turut adalah $81.46 \%$ dan $86.75 \%$. Dengan perkataan lain, hampir semua responden tidak pernah terlibat dalam kecelakaan dan pelanggaran lalu lintas selama 1 tahun terakhir.

Memperhatikan TPB seperti yang terlihat pada Gambar 1, hipotesis pada awalnya disusun untuk menguji hubungan antara variabel-variabel yang ada pada Tabel 1. Hipotesis yang disusun adalah sebagai berikut:

1. $\mathrm{H}_{1}$ : faktor demografi, keterlibatan dalam kecelakaan dan pelanggaran lalu lintas, catatan berkendara, dan berkendara pada ruas jalan nasional diduga berpengaruh kepada tujuan pengendara ngebut di jalan raya.

2. $\mathrm{H}_{2}$ : persepsi rambu kecepatan diduga berpengaruh kepada tujuan pengendara ngebut di jalan raya.

3. $\mathrm{H}_{3}$ : sikap pengendara diduga berpengaruh kepada tujuan pengendara ngebut di jalan raya.

4. $\mathrm{H}_{4}$ : tujuan pengendara ngebut di jalan raya diduga berpengaruh kepada prilaku ngebut di jalan raya.

5. $\mathrm{H}_{5}$ : sikap pengendara diduga berpengaruh kepada persepsi pengendara terhadap persepsi terhadap rambu kecepatan atau sebaliknya.

6. $\mathrm{H}_{6}$ : faktor demografi, keterlibatan dalam kecelakaan dan pelanggaran lalu lintas, catatan berkendara, dan berkendara pada ruas jalan nasional diduga berpengaruh kepada persepsi pengendara terhadap rambu kecepatan atau sebaliknya.

7. $\mathrm{H}_{7}$ : faktor demografi, keterlibatan dalam kecelakaan dan pelanggaran lalu lintas, catatan berkendara, dan berkendara pada ruas jalan nasional diduga berpengaruh kepada sikap ngebut pengendara di jalan raya.

Seperti yang diperlihatkan pada Gambar 2, struktur dari model konseptual disusun sesuai dengan TPB. Variabel laten disusun dan dihubungkan dengan klasifikasi variabel pada Tabel 1 dan hipotesis.

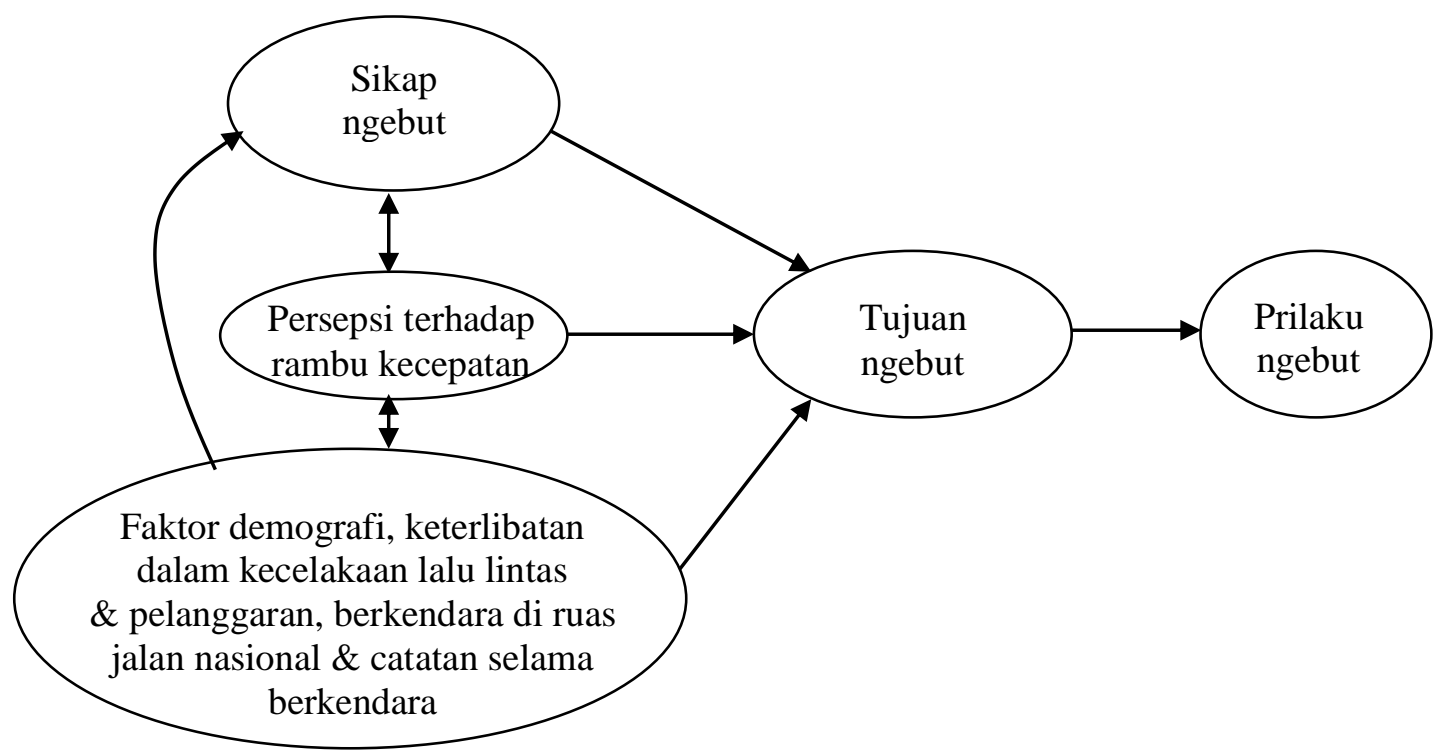

Gambar 2. Model konseptual 
Gambar 2 memperlihatkan modal konseptual dari tujuan dan prilaku ngebut yang disusun dalam alur tiga (3) tingkat pengaruh. Model ini dimulai dari variabel eksogen yang terdiri dari sikap ngebut dari penduduk lokal dan wisatawan mancanegara (variabel teramati dari AS22a sampai AS22k) saling terhubung dengan persepsi terhadap rambu kecepatan (variabel teramati dari SS1 sampai SS6) yang saling terhubung dengan kelompok faktor demografi (variabel teramati dari DF1 sampai DF3), keterlibatan dalam kecelakaan dan pelanggaran lalu lintas (variabel teramati dari AO1 sampai AO2), pengalaman berkendara pada ruas jalan nasional (variabel teramati dari NR1 sampai NR2) dan catatan selama berkendara (variabel teramati dari RH1 sampai RH4). Variabel endogen adalah tujuan ngebut (variabel teramati dari IS23a to IS23k) yang juga merupakan variabel eksogen untuk prilaku ngebut (variabel teramati dari BS24a sampai BS24g).

\section{HASIL PENELITIAN DAN ANALISIS}

Untuk penentuan variabel yang disertakan di dalam model, setiap variabel sikap, tujuan dan prilaku ngebut yang direpresentasikan pada data ordinal dan terdiri dari 33 pertanyaan nomor AS22a-22k, IS23a-23k dan BS24a-24k dalam Tabel 1 dianalisis dengan metode Analisis Komponen Utama (PCA). Metode variansi maksimum (MVM) digunakan untuk penentuan komponen-komponen utama. Tabel 2 menggambarkan variabel laten dan teramati yang signifikan dengan variansi lebih dari $20 \%$ dan faktor-faktor pembebanan (loading factors) diukur dengan Cronbach' Alpha lebih dari 0.7 (Hooper, et.al, 2008).

Tabel 2. Pemilihan variabel sikap dan tujuan menggunakan PCA

\begin{tabular}{|c|c|c|c|c|}
\hline Faktor & $\%$ Variansi & Pertanyaan No. & Loading & Cronbach Alpha \\
\hline \multicolumn{5}{|c|}{ Penduduk Lokal } \\
\hline \multirow{3}{*}{$\begin{array}{l}\text { Percaya diri dan bangga menjadi } \\
\text { pengendara kendaraan bermotor }\end{array}$} & \multirow{3}{*}{$31.19 \%$} & $\mathrm{AS} 22 \mathrm{~h}$ & 0.837 & \multirow{3}{*}{0.881} \\
\hline & & AS22i & 0.859 & \\
\hline & & AS $22 j$ & 0.830 & \\
\hline \multirow{5}{*}{ Pelepasan dan pujian } & \multirow{5}{*}{$42.83 \%$} & IS23c & 0.759 & \multirow{5}{*}{0.870} \\
\hline & & IS23d & 0.828 & \\
\hline & & IS23e & 0.731 & \\
\hline & & IS23j & 0.780 & \\
\hline & & IS23k & 0.801 & \\
\hline \multirow{2}{*}{ Tepat waktu sampai di tujuan } & \multirow{2}{*}{$20.43 \%$} & IS23a & 0.842 & \multirow{2}{*}{0.653} \\
\hline & & IS $23 b$ & 0.769 & \\
\hline \multicolumn{5}{|c|}{ Wisatawan Mancanegara } \\
\hline \multirow{7}{*}{ Alasan untuk ngebut } & \multirow{7}{*}{$49.16 \%$} & $\mathrm{AS} 22 \mathrm{a}$ & 0.703 & \multirow{7}{*}{0.936} \\
\hline & & AS22d & 0.773 & \\
\hline & & AS22g & 0.853 & \\
\hline & & AS22h & 0.911 & \\
\hline & & $\mathrm{AS} 22 \mathrm{i}$ & 0.915 & \\
\hline & & AS22j & 0.747 & \\
\hline & & AS22k & 0.766 & \\
\hline
\end{tabular}




\begin{tabular}{|c|c|c|c|c|}
\hline Faktor & $\%$ Variansi & Pertanyaan No. & Loading & Cronbach Alpha \\
\hline \multirow{2}{*}{$\begin{array}{l}\text { Ngebut karena alasan keluarga dan ada } \\
\text { polisi }\end{array}$} & \multirow{2}{*}{$23.14 \%$} & $\mathrm{AS} 22 \mathrm{~b}$ & 0.803 & \multirow{2}{*}{0.717} \\
\hline & & AS22e & 0.886 & \\
\hline \multirow{9}{*}{ Pelepasan, pujian dan hobi } & \multirow{9}{*}{$53.96 \%$} & IS $23 \mathrm{c}$ & 0.845 & \multirow{9}{*}{0.957} \\
\hline & & IS23d & 0.829 & \\
\hline & & IS23e & 0.782 & \\
\hline & & IS23f & 0.784 & \\
\hline & & IS23g & 0.728 & \\
\hline & & IS23h & 0.828 & \\
\hline & & IS23i & 0.786 & \\
\hline & & IS $23 \mathrm{j}$ & 0.893 & \\
\hline & & IS23k & 0.702 & \\
\hline \multirow{2}{*}{ Tepat waktu sampai di tujuan } & \multirow{2}{*}{$24.81 \%$} & IS23a & 0.916 & \multirow{2}{*}{0.925} \\
\hline & & IS23b & 0.901 & \\
\hline
\end{tabular}

Terkait dengan pengendara lokal, faktor pembebanan dari tiga (3) variabel teramati dalam variabel laten percaya diri dan bangga menjadi pengendara kendaraan bermotor terdiri dari pertanyaan nomor AS22h (ngebut membuat saya lebih percaya diri terkait kemampuan saya mengendarai kendaraan bermotor), AS22i (ngebut membuat saya bangga karena membuat saya mampu mendahului kendaraan lain), dan AS22j (tidak ngebut menandakan saya pengendara yang tidak bernyali). Variabel laten pelepasan dan pujian terdiri dari variabel teramati IS23c (ngebut untuk uji nyali), IS23d (ngebut mengurangi stress), IS23e (ngebut untuk menyalurkan hobi), IS23j (karena ngebut saya dapat pujian) dan IS23k (ngebut bisa lolos dari kejaran polisi).

Sementara itu, terkait pengendara wisatawan mancanegara, faktor-faktor pembebanan dari tujuh (7) variabel teramati pada kelompok alasan untuk ngebut terdiri dari pertanyaan AS22a (teman-teman mendukung saya untuk ngebut), AS22d (pengemudi lain menginginkan saya untuk ngebut), AS22g (ngebut membuat saya bebas untuk penyaluran emosi), AS22h (ngebut menumbuhkan percaya diri terkait kemampuan berkendara), AS22i (ngebut menumbuhkan kebanggaan karena dapat mendahului kendaraan lain), AS22j (tidak ngebut mengindikasikan pengendara yang tidak bernyali) and AS22k (ngebut menimbulkan kesenangan dalam berkendara).

Variabel laten ngebut karena alasan keluarga dan ada polisi terdiri dari variabel teramati AS22b (keluarga saya mengijnkan saya ngebut saat kondisi darurat) dan AS22e (polisi lebih memperhatikan kelengkapan surat-surat dibandingkan pengendera yang ngebut). Selain itu, suatu variabel laten pelepasan, pujian dan hobi terdiri dari variabel teramati IS23c (ngebut untuk uji nyali), IS23d (ngebut mengurangi stres), IS23e (ngebut sebagai penyaluran hobi), IS23f (ngebut mengurangi kantuk), IS23g (ngebut meningkatkan konsentrasi), IS23h (ngebut untuk memperlihatkan kemampuan berkendara ke pengendara lain), IS23i (ngebut untuk melepaskan kemarahan), IS23j (ngebut untuk dapat pujian dari orang-orang sekitar) dan IS23k (ngebut agar lolos dari kejaran polisi).

Pengendara penduduk lokal dan wisatawan mancanegara berbagi faktor yang sama terkait ketepatan waktu untuk mencapai tujuan yang terdiri dari variabel teramati IS23a (ngebut 
menyebabkan sampai tempat tujuan lebih cepat) dan IS23b (ngebut menyebabkan sampai tempat tujuan tepat waktu). Tabel 2 memperlihatkan bahwa variabel-variabel teramati mencapai konsistensi internal relatif saat nilai variabel lebih dari 0.70 dan juga memperlihatkan faktor sikap dan tujuan dan variabelnya diikutsertakan saat penyusunan model. Akan tetapi, variabel laten prilaku ngebut tidak berpengaruh secara signifikan, sehingga tidak diikutsertakan dalam model. Hal ini ditunjukkan oleh variansi dan faktor pembebanan berturut-turut kurang dari $20 \%$ dan 0.7 .

SEM digunakan untuk menjelaskan hubungan antara variabel laten dengan variabel teramati. Variabel laten meniadakan semua kesalahan pengamatan agar dapat diperoleh koefisien yang valid. Selain itu, semua koefisien di dalam SEM ditentukan secara simultan oleh karenanya signifikansi dan kekuatan hubungan di dalam model dapat dievaluasi. SEM dapat dianggap sebagai suatu kelompok dua (2) tipe teknik statistik yaitu Analisis Faktor dan Model Persamaan Simultan. Variabel eksogen atau endogen dalam SEM dapat mempunyai hubungan tidak langsung, berganda dan terbalik (Hair et al. (2010). Pada studi ini, SEM disusun menggunakan IBM SPSS AMOS software (versi 23). Untuk penjelasan lebih detail terkait PCA dan SEM, dapat dilihat pada Hair et al. (2010).

Tabel 3 memperlihatkan hubungan antara variabel laten, variabel tidak laten, variabel eksogen dan variabel endogen yang signifikan 5\% secara statistik dari model pengendara penduduk lokal dan wisatawan mancanegara. Variabel-variabel faktor demografi, keterlibatan dalam kecelakaan dan pelanggaran lalu lintas, pengalaman berkendara pada ruas jalan nasional dan catatan berkendara (DF) berpengaruh negatif dan signifikan kepada persepsi terhadap rambu kecepatan bagi pengendara lokal dan sikap ngebut (AS) bagi wisatawan mancanegara. Selain itu, sikap ngebut (AS) berpengaruh positif dan signifikan kepada tujuan ngebut (IS) dari pengendara lokal. Dengan perkataan lain, faktor demografi, keterlibatan dalam kecelakaan dan pelanggaran lalu lintas, pengalaman berkendara pada ruas jalan nasional dan catatan berkendara (DF) berpengaruh secara negatif dan signifikan dengan cara yang berbeda-beda baik kepada pengendara penduduk lokal maupun wisatawan mancanegara.

Terdapat dua (2) variabel teramati berpengaruh signifikan kepada sikap ngebut (AS22) bagi pengendara lokal yang terdiri AS22i (ngebut menumbuhkan kebanggan karena dapat mendahului kendaraan lain) dan AS22j (tidak ngebut mengindikasikan pengendara tidak bernyali). Sementara itu, delapan (8) variabel teramati dari sikap ngebut (AS22) berpengaruh secara signifikan kepada wisatawan mancanegara terdiri dari AS22a (temanteman menudukung saya untuk ngebut), AS22d (pengendara lain menginginkan saya untuk berkendara dengan kecepatan tinggi), AS22e (polisi lebih memperhatikan kelengkapan surat-surat dibandingkan pengendera yang ngebut), AS22h (ngebut menumbuhkan percaya diri terkait kemampuan berkendara), AS22i (ngebut menumbuhkan kebanggaan karena dapat mendahului kendaraan lain ), AS22j (tidak ngebut mengindikasikan pengendara yang tidak bernyali), AS22k (ngebut menimbulkan kesenangan dalam berkendara) dan AS22g (ngebut membuat saya bebas untuk penyaluran emosi). 
Tabel 3. Hasil pemodelan pengendara penduduk lokal dan wisatawan mancanegara

\begin{tabular}{ccccc}
\hline \multicolumn{5}{c}{ Pengendara Penduduk Lokal } \\
\hline & Alur & & Koefisien & p-value \\
\hline SS & $\leftarrow$ & DF & -0.036 & 0.049 \\
IS & $\leftarrow$ & AS & 0.328 & $<0.001$ \\
\hline AS22i & $\leftarrow$ & AS22 & 1.051 & $<0.001$ \\
\hline AS22j & $\leftarrow$ & AS22 & 0.814 & $<0.001$ \\
\hline IS23a & $\leftarrow$ & IS23 & 1.191 & $<0.001$ \\
\hline IS23e & $\leftarrow$ & IS23 & 1.861 & $<0.001$ \\
\hline IS23k & $\leftarrow$ & IS23 & 1.400 & $<0.001$ \\
\hline IS23d & $\leftarrow$ & IS23 & 1.877 & $<0.001$ \\
\hline IS23c & $\leftarrow$ & IS23 & 1.745 & $<0.001$ \\
\hline SS1 & $\leftarrow$ & SS & 6.242 & 0.011 \\
\hline SS3 & $\leftarrow$ & SS & 0.908 & 0.030 \\
\hline SS4 & $\leftarrow$ & SS & 4.572 & 0.011 \\
\hline SS2 & $\leftarrow$ & SS & 3.938 & 0.009 \\
\hline RH3 & $\leftarrow$ & DF & 5.791 & $<0.001$ \\
\hline RH2 & $\leftarrow$ & DF & -0.709 & $<0.001$ \\
\hline NR1 & $\leftarrow$ & DF & 1.027 & $<0.001$ \\
\hline
\end{tabular}

\begin{tabular}{ccccc}
\hline \multicolumn{4}{c}{ Pengendara Wisatawan Mancanegara } \\
\hline Alur & & Koefisien & p-value \\
\hline AS & $\leftarrow$ & DF & -1.998 & 0.035 \\
\hline AS22a $\leftarrow$ & AS22 & 1.528 & $<0.001$ \\
\hline AS22d $\leftarrow$ & AS22 & 1.490 & $<0.001$ \\
\hline AS22e $\leftarrow$ & AS22 & 0.707 & 0.002 \\
\hline AS22h $\leftarrow$ & AS22 & 1.891 & $<0.001$ \\
\hline AS22i $\leftarrow$ & AS22 & 1.813 & $<0.001$ \\
\hline AS22j $\leftarrow$ & AS22 & 1.527 & $<0.001$ \\
\hline AS22k $\leftarrow$ & AS22 & 1.697 & $<0.001$ \\
\hline AS22g $\leftarrow$ & AS22 & 1.134 & $<0.001$ \\
\hline IS23b $\leftarrow$ & IS23 & 0.927 & $<0.001$ \\
\hline IS23c $\leftarrow$ & IS23 & 1.268 & $<0.001$ \\
\hline IS23d $\leftarrow$ & IS23 & 1.225 & $<0.001$ \\
\hline IS23e $\leftarrow$ & IS23 & 1.274 & $<0.001$ \\
\hline IS23f $\leftarrow$ & IS23 & 1.161 & $<0.001$ \\
\hline IS23h $\leftarrow$ & IS23 & 1.185 & $<0.001$ \\
\hline IS23j & $\leftarrow$ & IS23 & 1.284 & $<0.001$ \\
\hline IS23k $\leftarrow$ & IS23 & 1.214 & $<0.001$ \\
\hline IS23g $\leftarrow$ & IS23 & 1.134 & $<0.001$ \\
\hline AO2 & $\leftarrow$ & DF & -6.732 & 0.026 \\
\hline$<0.001$ & & & &
\end{tabular}

Catatan : Kedua model mempunyai nilai signifikansi p value $<0.001$

Sementara itu, lima (5) variabel teramati secara signifikan berpengaruh kepada tujuan ngebut (IS23) bagi pengendara lokal yang terdiri dari IS23a (dengan ngebut mencapai tujuan lebih cepat), IS23e (ngebut sebagai penyaluran hobi), IS23k (dengan ngebut dapat lolos dari kejaran polisi), IS23d (ngebut mengurangi stres) dan IS23c (ngebut untuk uji nyali). Sementara itu, sembilan (9) variabel teramati dari tujuan ngebut (IS23) berpengaruh secara signifikan kepada wisatawan mancanegara terdiri dari IS23b (dengan ngebut lebih cepat sampai di tujuan tepat waktu), IS23c (ngebut untuk uji nyali), IS23d (ngebut mengurangi stres), IS23e (ngebut untuk penyaluran hobi), IS23f (ngebut mengurangi ngantuk), IS23h (ngebut untuk memperlihatkan kemampuan berkendara ke pengendara lain), IS23j (dengan ngebut dapat pujian dari pengendara lain), IS23k (ngebut untuk lolos dari kejaran polisi) dan IS23g (ngebut untuk meningkatkan konsentrasi di jalan).

Variabel-variabel teramati pada variabel laten dari persepsi terhadap rambu keselamatan (SS) hanya berpengaruh kepada pengendara penduduk lokal. Variabel-variabel teramati tersebut terdiri dari SS1 (menjaga batas kecepatan sesuai dengan rambu kecepatan), SS2 (rambu kecepatan untuk memantau kecepatan kendaraan), SS3 (rambu batas kecepatan untuk memperbaiki keselamatan lalu lintas) dan SS4 (rambu batas kecepatan untuk mengurangi waktu tempuh). Sementara itu, variabel-variabel teramati lainnya terkait 
dengan laten variabel faktor demografi, dll (DF). Tipe kendaraan yang paling banyak dikendarai (RH2) dan frekuensi berkendara pada ruas jalan nasional (NR1) berpengaruh kepada pengendara penduduk lokal, sementara variabel keterlibatan dalam pelanggaran selama 12 bulan terakhir berpengaruh kepada wisatawan mancanegara.

\section{KESIMPULAN DAN SARAN}

Tiga (3) dari tujuh (7) hipotesis yang telah disusun dapat dipenuhi pada penelitian ini. Faktor-faktor demografi, keterlibatan dalam kecelakaan dan pelanggaran lalu lintas, pengalaman berkendara pada ruas jalan nasional dan catatan berkendara mempunyai pengaruh negatif (berbanding terbalik) dan signifikan kepada persepsi pengendara terhadap rambu kecepatan $\left(\mathrm{H}_{6}\right)$ bagi penduduk lokal dan sikap ngebut $\left(\mathrm{H}_{7}\right)$ bagi wisatawan mancanegara. Selain itu sikap ngebut mempunyai pengaruh positif (berbanding lurus) dan signifikan kepada tujuan ngebut $\left(\mathrm{H}_{3}\right)$ bagi pengendara lokal.

Penduduk lokal atau wisatawan mancanegara mempunyai faktor-faktor terpisah yang berpengaruh kepada persepsi mereka terhadap batas kecepatan pada ruas jalan nasional di Bali. Hasil studi ini dapat digunakan sebagai dasar untuk penyusunan target kampanye keselamatan lalu lintas baik untuk penduduk lokal maupun wisatawan mancanegara.

Terkait dengan penegakan hukum batas kecepatan, penduduk lokal memerlukan perhatian yang lebih dibandingkan wisatawan mancanegara. Hal ini terlihat dari banyaknya faktorfaktor yang berpengaruh pada penduduk lokal dibandingkan wisatawan mancanegara. Hasil studi ini juga menyarankan bahwa pengenalan keselamatan lalu lintas harus secara formal mulai dilakukan pada pendidikan usia dini, sekolah dasar dan menengah di Indonesia.

\section{UCAPAN TERIMA KASIH}

Penelitian ini didanai oleh Pusat Penelitian Kecelakaan Lalu lintas (Traffic Accident Research Center /TARC), Direktorat Keamanan dan Keselamatan Korlantas Polri.

\section{DAFTAR PUSTAKA}

Ajzen, I. 1991. The theory of planned behavior. Organizational Behavior and Human Decision Processes, 50, pp. 179-211.

Duong, H.T. and Parker, L. 2018. Going with the flow: Young motorcyclists' misperceived norms and motorcycle speeding behaviour. Journal of Social Marketing, (8)3, pp. 314-332.

Hair, J.F., Black, W.C., Babin, B.J., and Anderson, R.E. 2010. Multivariate Data Analysis $7^{\text {th }}$ Edition. Pearson Prentice Hall, New York.

Hooper, D., Coughlan, J. and Mullen, M., 2008. Structural Equation Modelling: Guidelines for Determining Model Fit. Electronic Journal of Business Research Methods, 6(1), pp. 53-60.

Joewono, T.B., Vandebona, U. and Susilo, Y.O. 2015. Behavioural Causes and Categories of Traffic Violations by Motorcyclists in Indonesian Urban Roads. Journal of Transport Safety and Security, 7(2), pp. 174-197. 
Kaplan, S., Bortei-Doku, S. and Prato, C.G. 2018. The Relation between The Perception of Safe Traffic and The Comprehension of Road Signs in Conditions of Ambiguous and Redundant Information. Transportation Research Part F, 55, pp. 415-425.

Nutsugbodo, R.Y., Amenumey, E.K. and Mensah, C.A. 2018. Public Transport Mode Preferences of International Tourists in Ghana: Implications for Transport Planning. Travel Behaviour and Society, 11, pp. 1-8.

Rhodes, N. and Pivik, K. 2011. Age and Gender Differences in Risky Driving: The Roles of Positive Affect and Risk Perception. Accident Analysis and Prevention, 43 (3), pp. 923-931.

Badan Pusat Statistik Provinsi Bali. 2018. Bali dalam Angka. Pemerintah Daerah Provinsi Bali.

Susilo, Y.O., Joewono, T.B. and Vandebona, U. 2015. Reasons Underlying Behaviour of Motorcyclists Disregarding Traffic Regulations in Urban Areas of Indonesia. Accident Analysis and Prevention, 75, pp. 272-284.

Ulleberg, P. and Rundmo, T. 2003.. Personality, Attitudes and Risk Perception as Predictors of Risky Driving Behaviour among Young Drivers. Safety Science, 41, pp. 427-443.

Wedagama, D.M.P. 2017. The Influence of Motorcyclists' Attitudes on Traffic Accidents and Offences. Jurnal Teknik Sipil ITB, 24(2), pp. 117-124. 